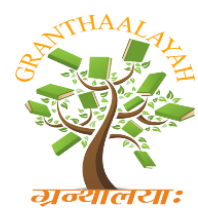

INTERNATIONAL JOURNAL OF RESEARCH GRANTHAALAYAH

A knowledge Repository

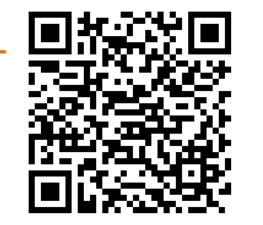

Management

\title{
SOCIO-ECONOMIC STATUS OF SCHEDULED TRIBES IN KALRAYAN HILLS
}

\author{
Prof. A. Jayakumar ${ }^{* 1}$, P. Palaniyammal ${ }^{2}$ \\ ${ }^{* 1}$ Professor of Commerce \& Former Controller of Examinations, Periyar University, Salem, \\ INDIA \\ ${ }^{2}$ Ph.D., Research Scholar, Department of Commerce, Periyar University Salem, INDIA
}

\begin{abstract}
Social and economic justice, equality of status and opportunities and cultural and educational status are insured by the Constitution of India for all citizens and also provide enriched provisions for scheduled caste and tribes. This paper addresses the socio economic status of the scheduled tribes in kalrayan hills Salem district Tamilnadu (India). The majority of the household occupations are Agriculture. Cultivation is the primary occupation participated by the most heads of the sample households. Income from cultivation support majority of the sample population. More than 83 percent of the agriculture has from income around below $R s$ 5000-10000 level. Even daily wage labours are present in the sample population. There is a need to put more attention on educational aspects of scheduled tribes, where this only can motivate them for future life.
\end{abstract}

Keywords:

Socio Economic Status, Tribal People, agriculture, Kalrayan Hills, Salem District, Tamilnadu.

Cite This Article: Prof. A. Jayakumar, and P. Palaniyammal, "SOCIO-ECONOMIC STATUS OF SCHEDULED TRIBES IN KALRAYAN HILLS" International Journal of Research Granthaalayah, Vol. 4, No. 3: SE (2016): 22-30.

\section{INTRODUCTION}

Development of the tribal's should be according to the "lines of their own thinking" -Jawaharlal Nehru

The tribal population is identified as the aboriginal inhabitants of our country. For centuries, they have been living a simple life based on the natural environment and have developed cultural patterns congenial to their physical and social environment. References of such tribal groups are found even in the literature on the ancient period, right from the Ramayana and the Mahabharata periods (Mehta, 2000). According to L.P.Vidyarthi tribe is a social group with definite territory, common name, common descent, common culture, behavior of an endogamous group, common taboos, existence of distinctive social and political system, and full faith in leaders and self- 
sufficiency in their distinct economy (Vidyarthi, 1981). There are approximately two hundred million tribal people in the entire globe, which means, about $4 \%$ of the global population. They are found in many regions of the world and majority of them are the poorest amongst poor. According to India's most recent census in 2011 Schedule tribes comprise $8.6 \%$ of the population.

\section{SCHEDULED TRIBES IN INDIA}

Scheduled Tribes (STs) are indigenous, have their own distinctive culture, are geographically isolated and are low in socio-economic conditions. For centuries, the tribal groups have remained outside the realm of the general development process due to their habitation in forests and hilly tracts. After independence, Government of India has scheduled the tribal groups in the Constitution and provided special provisions for their welfare and developments in the case of ST communities across the States in India and 75of the STs are most backward and are termed as Primitive Tribal Groups. Most of the tribal areas are hilly, inaccessible undulating plateau lands in the forest areas of the country resulting in the bypassing of general developmental programmes. Due to this, infrastructure and development facilities in tribal areas for education, roads, healthcare, communication, drinking water, sanitation etc.

Lagged behind compared to other area which has India being the second largest tribal dominated area after Africa is one of the most fascinating Nations of World from anthropological point of view. The total tribal populations of India, is 8.6 per cent (census of India, 2011). As many as 550 tribal communities are residing in India, of whom 75 are declared as primitive tribal groups who are spread across the country. The tribal population is identified as the aboriginal inhabitants of our country. They are seen in almost every State of India. For centuries, they have been living a simple life based on the natural environment and have developed cultural patterns congenial to their physical and social environment. References of such tribal groups are found even in the literature on the ancient period, right from the Ramayana and the Mahabharata period.

Percentage of Scheduled Tribes in State's total population, India (1981-2011)

\begin{tabular}{|l|l|l|l|l|}
\hline NORTH EASTERN REGION & 1981 & 1991 & 2001 & 2011 \\
\hline Assam & & 12.82 & 12.4 & 12.4 \\
\hline Manipur & 27.30 & 34.41 & 34.2 & 35.1 \\
\hline Mehalaya & 80.58 & 85.53 & 85.9 & 86.1 \\
\hline Nagaland & 83.99 & 87.70 & 89.1 & 86.5 \\
\hline Tripura & 28.44 & 30.95 & 31.1 & 31.8 \\
\hline Arunachal Pradesh & 69.82 & 63.66 & 64.2 & 68.8 \\
\hline Sikkim & 23.27 & 22.36 & 20.6 & 33.8 \\
\hline Mizoram & 93.55 & 94.75 & 94.5 & 94.4 \\
\hline NORTHERN & & & & \\
\hline Himachal pradesh & 4.61 & 4.22 & 4 & 5.7 \\
\hline
\end{tabular}




\begin{tabular}{|l|l|l|l|l|}
\hline Uttar pradesh & 0.21 & 0.21 & 0.1 & 0.6 \\
\hline CENTRAL & & & & \\
\hline Madhya pradesh & 22.97 & 23.27 & 20.3 & 21.1 \\
\hline WESTERN & & & & \\
\hline Gujarat & 14.22 & 14.92 & 14.8 & 14.8 \\
\hline Maharashtra & 9.19 & 9.27 & 8.9 & 9.4 \\
\hline Rajasthan & 12.21 & 12.44 & 12.6 & 13.5 \\
\hline Dadra and Nagar Haveli & 78.82 & 78.99 & 62.2 & 52 \\
\hline Goa & 0.99 & 0.03 & 0 & 10.8 \\
\hline Daman and Diu & & 11.54 & 6.3 & 6.3 \\
\hline SOUTHERN & & & & \\
\hline Andra pradesh & 5.93 & 6.31 & 8.8 & 6.3 \\
\hline Kerala & 1.03 & 1.10 & 1.1 & 1.5 \\
\hline Karnataka & 4.91 & 4.26 & 6.6 & 7 \\
\hline Tamil Nadu & 1.07 & 1.03 & 1 & 1.1 \\
\hline ISLAND & & & & \\
\hline Andaman and Nicobar & 11.85 & 9.54 & 8.3 & 7.5 \\
\hline Lakshadweep & 93.82 & 93.15 & 94.5 & 94.8 \\
\hline
\end{tabular}

Sources: census report 2011

\section{SCHEDULED TRIBES POSITION IN TAMILNADU}

The scheduled tribes are constitutes $1.1 \%$ ( 0.79 million) in the total population of 72.14 million of Tamil Nadu as per census 2011 which represents $0.76 \%$ in the total population of India and it constitutes 36 castes. Among the 36 STs, five STs are sharing majority of $80.32 \%$ in the state ST population namely Malayali, Irular, Kattunayakan, Kurumans and Uraly.

The human society plays a major role in the world we live in, even though the other parts and its nature are not understood. Come what may people think of them as spaced out from rest of the natural world. Human societies are unique in either way or other, still however they are found to share many vital characteristics. Hence at the onset it is necessary to establish the societies in order and to bring out the consequences of his relationship (Winfred Thames, 1985).

Earlier ages before men lived in a society which survived on fierce hunting society and they purely depended on the existed natural sources within the survival limits. The incredibly increasing human and animal population, the pressured environment, the consumer markets and economics, the industrial development and other several related factors has resulted in the exploitation of natural resources. This has resulted to the degradation of forests, several 
environmental problems and has consequently led to the fall off of homeland of native tribal. The primitive methods of farming, agriculture, shifting cultivation and exploitation of the forest produces by the millions of people living within and out of the forest has lead to major forest loss.

Though India has bequethed unique flora and fauna by the nature, the Indian tradition and its heritage seems to be an amalgamation of a wide variety of colorful cultures. Urban, rural, folk, archaic and modern cultures are devised into the aboriginal civilization of India. Similarly the varied ethinicities, multi linguistics and diferent religion have been synchronized in Indian traditions. The Indian civilization is hence a plural society with a potpourri of traditions.

\section{IMPORTANCE OF THE STUDY}

The main problem in the society is that there is no proper awareness and understanding the tribal people. In government point of view, even the government has taken lot of schemes benefiting to them; the whole benefits not reached them properly. Most bankers hesitate to give loans to them, because they don't have proper income and status in the society the aims of the study are to identify to what extent the concept of tribal people in Kalrayan Hills. In addition the study focuses on the need and importance of financial and non-financial support to overall well-being and empowerment of the tribal people in Kalrayan Hills.

\section{STATEMENT OF THE PROBLEM}

The economic problems need special attention in the context of tribal communities of India. Available research studies point out that the tribal population has distinctive health. Insanitary conditions, ignorance, ST population continue to carry burdens of ,diseases of the poor ${ }^{\text {ee }}$, namely under nutrition and infection diseases. They are dominated, exploited and controlled by the mainstream. The tribes in Kalrayan Hills have poor infrastructure facilities, the problems related to various aspects of tribal people in kalrayan hills viz. social, economical, educational, health, religion, an, law and order situation, self-centered tendency and so on, and they got meager facilities from the Government as the government schemes normally designed for the average district or village, which is not a reality where tribes are concerned.

\section{OBJECTIVES}

1) To study the socio economic condition of tribal people at Kalrayan Hills.

2) To study the educational facility available for tribal people at Kalrayan Hills.

3) To identify the resources available in Kalrayan Hills.

\section{RESEARCH METHODOLOGY}

There are various methods to conduct research study. The feels that questionnaire methods are more suitable. In this methods researcher prepare different questions, from a questionnaire and give to respondents. Whenever respondents feel any doubt with regard to any question it may be easily clarified by the researcher. Also the researcher adopts sampling methods to conduct the study. 


\section{RESEARCH DESIGN}

Kalrayan Hills region has been selected for the study, because the researcher has observed that the regional has sufficient number of ST population for the study, the following hills are taken to study Kalrayan hills from Salem district.

\section{DATA COLLECTION METHOD}

\section{PRIMARY DATA}

The data was collected through well-structured questionnaire, which comprises of general information, for socioeconomic condition in tribal people.

\section{SECONDARY DATA}

The secondary data was collected through various books, journals, articles ${ }^{e e}$, periodicals, newspapers, websites, and theses.

\section{SAMPLE METHOD}

Convenient sampling has been adopted for the study. This sample was collected by convenient method to the accessibility and reliability of the respondents in Kalrayan Hills region.

\section{SAMPLE SIZE}

The total sample consists of 150 respondents from Kalrayan Hills region.

\section{TOOLS USED FOR ANALYSIS}

Various tools used and graphical representation is made for easy understanding of the analysis like as simple percentage method.

\section{LIMITATIONS OF THE STUDY}

The study is based on the options received from the socio economic condition of tribal people. The study mainly focused on the socio economic changes in tribal people.

The study is made to know the role of socio economic condition of tribal people in kalrayan Hills at Salem district. Incomplete and wrong information and non-responses to some questions could not be avoided. The data relating to Salem district are not available continuously for the period of the study. Hence the available data from the concerned area have been taken for the study.

Gender Wise Classification

\begin{tabular}{|l|l|l|}
\hline Gender & Frequency & percent \\
\hline Male & 95 & 64.0 \\
\hline Female & 55 & 36.0 \\
\hline Total & 150 & 100.0 \\
\hline
\end{tabular}

Source: Primary Data

The above table shows the gender of the respondents, $64 \%$ of the male respondents. $36 \%$ of the respondents opined that female responds. To conclude that majority of the male respondents are male. 
Source: Primary Data

Age Wise classification

\begin{tabular}{|l|l|l|}
\hline Age & Frequency & Percent \\
\hline Below 20 Years & 18 & 12.0 \\
\hline 21-30 Years & 76 & 51.0 \\
\hline 31-40 Years & 25 & 16.0 \\
\hline 41-50 Years & 16 & 11.0 \\
\hline Above 50 Years & 15 & 10.0 \\
\hline Total & 150 & 100.0 \\
\hline
\end{tabular}

The above table shows that $51 \%$ of respondents are in the age group of $21-30$ years, $16 \%$ of the respondents are come 31 to 40 years age category $12 \%$ of the respondents are come under Below 20 years age category, $11 \%$ of the respondents are $41-50$ age group, and $10 \%$ of the responded Above 50 years

\section{Educational Qualification Wise Classification}

\begin{tabular}{|l|l|l|}
\hline Educational Qualification & Frequency & Percent \\
\hline Uneducated & 63 & 42.0 \\
\hline primary & 45 & 30.0 \\
\hline SSLC & 28 & 19.0 \\
\hline HSC & 10 & 7.0 \\
\hline DEGREE & 4 & 2.0 \\
\hline Total & 150 & 100.0 \\
\hline
\end{tabular}

Source: Primary Data

The respondents are classified into four categories according to the qualification as SSLC, HSC, Under Graduate and Uneducated Table 4.4 portrays $42 \%$ of the respondents are at illiterate level, $30 \%$ of the respondents have complete their Primary school level (SSLC), 19\% of the respondents have complete their SSLC, 7\% of the respondents have complete their HSC Level and only $2 \%$ of the responded Degree level.

Occupation Wise classification Occupation

Source: Primary Data

\begin{tabular}{|l|l|l|}
\hline Occupation & Frequency & Percent \\
\hline Agriculture & 125 & 83.0 \\
\hline Private Employee & 7 & 5.0 \\
\hline Daily Wager & 15 & 10.0 \\
\hline Other & 3 & 2 \\
\hline Total & 150.0 & 100.0 \\
\hline
\end{tabular}

Form the above Table 4.7 state that $83 \%$ of the respondents are come Agriculture Occupations, $10 \%$ of the respondents are come Daily Wage category, $5 \%$ of the respondents are Private Employee, $2 \%$ of the respondents are other category.

Income Wise Classification

\begin{tabular}{|l|l|l|}
\hline Income & Frequency & Percent \\
\hline Below Rs. 5,000 & 45 & 30 \\
\hline Rs. 5, 001 - Rs.10,000 & 35 & 23.00 \\
\hline
\end{tabular}




\begin{tabular}{|l|l|l|}
\hline Rs. 10, 001 - Rs 15, 000 & 32 & 21.0 \\
\hline Above Rs. 15, 001 & 23 & 16.00 \\
\hline Above Rs. 15, 001 & 15 & 10.00 \\
\hline Total & 150 & 100.0 \\
\hline
\end{tabular}

Source: Primary Data

The above table 4.8 clearly shows that $30 \%$ of the respondents monthly income range from below 5,000, $23 \%$ of the respondents monthly income is between Rs. 5001-10000, $16 \%$ of the respondents monthly income is $10001-15000$, and only $10 \%$ of the respondents earns a monthly income range above Rs.15001.

\section{Land Holding Size}

\begin{tabular}{|l|l|l|}
\hline Land Holding Size & Frequency & Percent \\
\hline Below 1 Acre & 45 & 30.0 \\
\hline 2 to 3 Acre & 80 & 53.0 \\
\hline 3 to 4 Acre & 15 & 10.0 \\
\hline Above 4 Acre & 10 & 7.0 \\
\hline Total & 150.0 & 100.0 \\
\hline
\end{tabular}

Source: Primary Data

It is evident from the above table that 53.0 percent of the respondents are have 2 to 3 Acre land in their own, 30.0 percent of the respondents are have Below 1 Acre land in their own and 10.0 percent of the respondents are have 3 to 4 Acre and only 7.0 percent of the respondents are have Above 4 Acre.

Source: Primary Data

\begin{tabular}{|l|l|l|}
\hline \multicolumn{3}{|c|}{ Opinion about Loan } \\
\hline Loan Opinion & Frequency & Percent \\
\hline Yes & 135 & 90.0 \\
\hline No & 15 & 10.0 \\
\hline Total & 150 & 100.0 \\
\hline
\end{tabular}

The above table shows that $90 \%$ of the respondents are obtained bank loan from other bank, and $10 \%$ of the respondents are do not obtained bank loan from other bank.

Opinion about Financial institutions

\begin{tabular}{|l|l|l|}
\hline Financial institution & Frequency & Percent \\
\hline Co-Operative Bank & 80 & 53.0 \\
\hline Private bank & 25 & 17.0 \\
\hline SBI \& Nationalized Bank & 36 & 24.0 \\
\hline Other Institution & 9 & 6.0 \\
\hline Total & 150.0 & 100.0 \\
\hline
\end{tabular}

Source: Primary Data

From the above table reveals that 53.0 percent of the respondents are taken loan from cooperative and SBI \& Nationalized Bank, 24.0 percent of the respondents to get loan from private bank and 17.0 percent of the respondents and 6 percent . 
Purpose Loan

Source: Primary

\begin{tabular}{|l|l|l|}
\hline Purpose Loan & Frequency & Percent \\
\hline Self Employment & 10 & 7 \\
\hline Agriculture & 128 & 85 \\
\hline Business & 8 & 5 \\
\hline Others & 4 & 3 \\
\hline Total & 150.0 & 100.0 \\
\hline
\end{tabular}

From the above table shows that $85 \%$ of the respondents are opinion that agriculture purposes, $7 \%$ of the respondents are Self-employment, $5 \%$ of the respondents are Business purpose and $3 \%$ of the respondents are other purpose.

\section{SUGGESTION}

The socio economic condition is very important for in our life. The tribal people earn low level of income which does not fulfill the basic needs. The infrastructures like Road, Communication, Sanitation etc are poor in Kalrayan hills and also have poor economic status compared to other general people. The Government has to provide provisions like loan facility and other development programme to improve their economic level.

\section{CONCLUSION}

The Tamil Nadu Tribal communities are at present engaged in economic pursuits ranging from hunting to settled agriculture and urban or industrial callings. However, agriculture dominates the tribal economic scene in Tamil Nadu and hardly 2 percent of tribal workers are involved in non-agricultural pursuits. Forest land is the main asset possessed by the tribal is very low when compared to the total all Tamilnadu literacy level. Their miseries are compounded by a low level of infrastructural and social services and the existence of a greater inequality among the tribes.

Regarding educations, the respondents are aware of their educational status. Though the respondents are illiterates, they want their children to avail the education provided by the government. Transportation facilities are provided with bus facility. This shows that government has shown much interest in the development of the tribal peoples transport facility. Regarding the transportation facility, education and government measures for the developments of the tribal have made their significance and it had reached the tribal people is really appreciable. Banking institutions were generous in granting loans to tribals. In view of these facts, an attempt was made to study the socio-economic characteristics of tribes in Tamil Nadu with a special reference to the tribal belonging to the malayali community in kalrayan Hills, Salem district. To sum up the study finds that there is only a partial development in the socio-economic status of the tribe's people in the kalrayan Hills.

\section{REFERENCES}

[1] Dr. Varrier Elwin Committee (1960) "Report of the study team on tribal development programmes" (P.Shilu A.O Committee), Government of India New Delhi A.O Committee 
[2] Roy Burma (1978, "Land Alienation-A menance of Tribal Economy Tribe , VOL,X, NO.4,1978.

[3] Fender Thacker (1986), "socio-economic development of Tribes in India", Deep and Deep Publishers, New Delhi, 1986.

[4] M.Kunhaman1982, "Tribal Economy of Kerala:An intra Reginal analysis", New $D, 1982$.

[5] Dluiz (1962), "Tribes of kerala Pharatiya seva shahra”, 1962.

[6] Bakshi and Karan balers (2000)," social and Economic Development of Scheduled Tribes", Deep and Deep Publications Pvt.Ltd. New Delhi,2000

[7] A.N.Sharma (2002), Tribal Welfare and Development, Arup \& Sons, New Delhi.

[8] Dr.Sujata Kannongo (2010), Development programme and social Changes among the Tribal's, Mohit Publications, New Delhi.

[9] Suresh K Sharma (2010), "Tribes through the ages", vista international publishing house, New Delhi.

[10] P K Bhowmick (2005), “Tribal and sustainable development”, Kalpaz publications, New Delhi. 